\title{
PREVALENCE OF ANTIBODIES AGAINST HEPATITIS A VIRUS AMONG THE KUIKURO AND KAIABI INDIANS OF XINGU NATIONAL PARK, BRAZIL
}

\author{
Manuel Mindlin LAFER, Maria Isabel DE MORAES-PINTO \& Lily Yin WECKX
}

\begin{abstract}
SUMMARY
A seroprevalence study to detect total antibodies against Hepatitis A Virus was done with 220 samples from 589 Native Indians from Xingu National Park, Brazil, in five Kaiabi and Kuikuro villages, the most populous ethnic groups. Using a commercial immunoassay kit we detected $97.7 \%$ positive samples (95\% Confidence Interval: 95\%-99\%). We noticed a precocious seroconversion, before the age of six years, when the disease is usually asymptomatic. These results are similar to those found in the literature in non-Indian population studies of the Northern, Northeastern and West Central regions of Brazil. They suggest that it is not necessary to introduce vaccination against Hepatitis $\mathrm{A}$ in these highly endemic populations.
\end{abstract}

KEYWORDS: Hepatitis A; Antibodies; South American Indians; Serology.

\section{INTRODUCTION}

Hepatitis A is caused by the RNA Picornaviridae Hepatitis A Virus, transmitted predominantly by the fecal-oral route. It is a disease of universal distribution, with different degrees of endemicity - high, intermediate, low and very low - varying in geographic regions according to socioeconomic, hygiene and health conditions ${ }^{15,17}$. Hepatitis A may be asymptomatic or symptomatic - with or without ictericia. Asymptomatic infections predominate in infants and children. It is predominantly acute without sequelae. In $1 \%$ of the acute cases, however, fulminant fatal hepatitis can occur if not treated with liver transplantion ${ }^{17,19}$. Fulminant Acute Hepatitis A is in fact one of the indications for hepatic transplantation in Brazil' ${ }^{21}$. Unusually, benign relapse, non-cirrhotic cholestasis, aplastic anemia and autoimmune disease can occur ${ }^{17,19}$.

In highly endemic regions, infection usually occurs before the age of five years; it is either mildly symptomatic or asymptomatic, and there is a lower risk of outbreaks and epidemics. These characteristics change where socioeconomic and hygiene conditions improve: endemicity is reduced and the age of infection increases ${ }^{7,15}$. Lifelong immunity follows infection, and $\operatorname{IgG}$ antibodies against Hepatitis A Virus are usually present one to four weeks after the clinical symptoms ${ }^{19}$.

Hepatitis A seroprevalence studies in Brazil have shown different rates according to the period when sera were collected, but also to the socioeconomic background of the communities analyzed $d^{3,8,10,11,16,18,20,23}$.

Vaccination was suggested to interrupt the ongoing outbreaks that occur every five to 10 years in communities where there was a $30 \%$ to $40 \%$ seroprevalence before the age of five years. This was the case with the American Indians, among whom a maintained reduction of the high rates of the disease was possible with the introduction of Hepatitis A vaccine ${ }^{7}$. The vaccine has also been adopted in Israel, with a favorable cost-bennefit analysis ${ }^{9,13}$ and herd effect protection ${ }^{9}$. More recently, it has also been adopted in Argentina ${ }^{2}$ and the United States ${ }^{7}$.

The Brazilian Ministry of Health adopts an adapted and larger than the general vaccination schedule for Indian populations ${ }^{6}$. This schedule does not include vaccination against Hepatitis A Virus, partially due to the lack of recent studies ${ }^{5,12,15}$ in these populations to evaluate this need and justify the adoption of that measure. Therefore, our aim was to estimate the Hepatitis A seroepidemiology in a West Central bordering Northern region in Brazil, a geographically and culturally well defined Indigenous population territory.

\section{MATERIAL AND METHODS}

This study was performed between June and September 2001 at the Xingu Indigenous National Park, a 2,642,003 hectare area, located in the North of the Mato Grosso State, with a population of 3,919 inhabitants, as described elsewhere ${ }^{14}$. The research protocol was submitted to and approved by the Ethics Committee of the Federal University of São Paulo (UNIFESP) and by the National Ethics Committee of the Brazilian Ministry of Health. Written consent was obtained from the Park leaders, the community chiefs and the Indigenous health agents. Oral consent was obtained from all the subjects. We evaluated 220 individuals over one year old from a total 


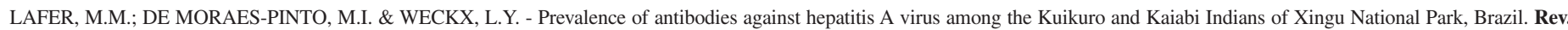
Inst. Med. trop. S. Paulo, 49(3): 155-157, 2007.

of 589 Native Indians from the Kuikuro and Kaiabi tribes. The villages assessed were the "Afukuri" and "Kuikuro" in the Southern region of the Park, where the Kuikuro Indians are located; in the Northern region, the "Capivara", "Guarujá" and "Tuiararé" villages, where the Kaiabi Indians live.

In both ethnic groups, the Kuikuro and the Kaiabi Indians, despite important cultural and linguistic differences, we found a similar circular disposition of the houses and health conditions. The number of houses in each Kaiabi village was: nine in the "Capivara" village, seven in "Guarujá" and 24 in "Tuiararé". In the Kuikuro villages, it was 10 in "Afukuri" and 20, in the "Kuikuro" village. The mean of inhabitants in each house in the five villages ranged from five to 12 .

Two hundred and twenty blood samples of $3 \mathrm{~mL}$ each were collected, according to the following criteria: one in two individuals below 20 years old and one in every four individuals above 20 years old. We did not analyze children below one year due to the possibility of false positive results because of the presence of maternal antibodies. Serum was separated and sent to the Research Laboratory of the Pediatric Infectious Diseases Division of the Federal University of São Paulo, where it was kept at $-20^{\circ} \mathrm{C}$ until analysis.

Results were obtained with a competitive immunoenzymatic assay using commercial kits BioRad ${ }^{\circledR}$, produced by DiaSorin (Italy). Concentrations of antibodies $20 \mathrm{mIU} / \mathrm{mL}$ or greater were considered to be protective ${ }^{1}$.

Statistical analysis was performed using Microsoft Excel ${ }^{\circledR} 2000$. Probabilities were assessed for 95\% significance and Fleiss' test was used to obtain more accurate confidence intervals of values close to $100 \%$ seroprevalence.

\section{RESULTS}

The prevalence of anti-HAV total antibodies found was $97.7 \%(95 \%$ Confidence Interval: 95\%-99\%) in the 220 samples from individuals over one year old. The ages of the five seronegative individuals were: two years (two individuals), three, four and six years; two of them belonged to the two Kuikuro Indians villages and the other three, to an unique Kaiabi village, the "Capivara" village. Serology results according to age groups are shown in Table 1.

Table 1

Total antibodies against hepatitis A virus according to age group in Brazilian Indigenous Communities from Xingu National Park

\begin{tabular}{lcccc}
\hline & \multicolumn{4}{c}{ Samples } \\
\cline { 2 - 5 } $\begin{array}{l}\text { Age group } \\
\text { (years) }\end{array}$ & $\mathrm{N}$ & Positive & Percentage & $\begin{array}{c}\text { 95\% Confidence } \\
\text { Interval }\end{array}$ \\
\hline 1 to 5 & 64 & 60 & 93.7 & $83-97$ \\
6 to 10 & 57 & 56 & 98.2 & $91-100$ \\
11 to 15 & 38 & 38 & 100.0 & $91-100$ \\
16 to 20 & 35 & 35 & 100.0 & $90-100$ \\
21 or more & 26 & 26 & 100.0 & $87-100$ \\
Total & 220 & 215 & 97.7 & $95-99$ \\
\hline
\end{tabular}

\section{DISCUSSION}

The results show a high seroprevalence of Hepatitis A in the Indigenous population of the Xingu National Park with a precocious onset. In fact, in high endemicity areas, infection occurs in the five first years of life, with few if any symptoms ${ }^{1,8,15}$. Data is also compatible with the $98 \%$ seroprevalence of hepatitis A among 352 Xicrin Indians ${ }^{15}$, among Parakanã and Asurini populations - 100\% $(\mathrm{n}=58)^{5}$ - and with the $96.6 \%$ seroprevalence found among the Katukinos of the occidental Amazon region, obtained from 32 individuals ${ }^{12}$.

All the assessed villages were located next to a river, from which the water supply came. The only exception being the "Kuikuro" village, which was close to a river, but had an artesian well dating from the year 2000. Every house in every village owned its cesspit. Each village had places to collect, burn and bury garbage, but the use of such places did not avoid the presence of garbage in inappropriate areas. Hand washing before meals or handling food by these indigenous groups may be less frequent than desired.

In North American Indian populations one study published in 1986 found a $70.1 \%$ seroprevalence of antibodies anti-HAV ${ }^{22}$, a high prevalence when compared to the United States' $45 \%$ seroprevalence in the adult population at that time, and is probably due to poorer sanitary conditions. However, immunization against Hepatitis A reduced the prevalence of the disease among American Indian and Alaskan natives ${ }^{4}$.

In Brazil, one study showed a total prevalence of $66.59 \%$ in the city of São Paulo ${ }^{11}$. Another study published in 2000 showed a $64.7 \%$ seroprevalence of hepatitis A in four different regions, in urban populations. In this study the 6-10 year group showed a $53.9 \%$ seroprevalence. Interestingly, only in the 11-15 year group the plato prevalence of $60.7 \%$ was reached, showing that infection still occurred after the age of 10 . Of note was the especially high result in the Northern region $(92.8 \%)^{8}$ when analyzed separately (data from the Central region was not avaliable).

Other studies performed in the Southeastern region of Brazil have shown lower seroprevalence rates, especially when groups with higher socioeconomic status were analyzed ${ }^{10,20,23}$. By contrast, studies performed in the Northern region showed a $86.4 \%$ seroprevalence of hepatitis A among children from two to nine years $(n=487)^{3}$, and $90.9 \%$ in riverine children from 0 to 10 years old $(n=22)^{16}$.

The precocious hepatitis A seroconversion observed in our study (93\% in the one to five year age group) does not suggest the need to introduce vaccination against the disease in native Indians from Xingu National Park: it would not prevent epidemics or the severe form of the disease that occurs in adolescents and adults.

\section{RESUMO}

\section{Prevalência de anticorpos contra o vírus da hepatite A entre os índios Kuikuro e Kaiabi do Parque Indígena do Xingu, Brasil}

Um estudo de soroprevalência para detectar anticorpos totais contra o Vírus da Hepatite A foi realizado com 220 amostras obtidas de 589 indivíduos de cinco aldeias indígenas das tribos Kaiabi e Kuikuro, as 
mais populosas do Parque Nacional do Xingu, Brasil. Utilisando um kit comercial de ensaio imunoenzimático, detectamos 97,7\% amostras positivas (Intervalo de Confiança de 95\%: 95\%-99\%), com uma soroconversão precoce, antes dos seis anos de idade, quando a doença costuma ser assintomática. Estes resultados são semelhantes aos resultados encontrados na literatura em estudos com populações nãoindígenas das regiões Norte, Nordeste e Centro-Oeste do Brasil, e sugere que não há necessidade de introdução de vacinação contra Hepatite $\mathrm{A}$ nestas populações de alta endemicidade.

\section{ACKNOWLEDGEMENTS}

We thank the Department of Pediatrics of the São Paulo Federal University (UNIFESP), for providing the kits used in the serology tests.

\section{REFERENCES}

1. AMERICAN ACADEMY OF PEDIATRICS - Hepatitis A. In: PICKERING, L.K., ed. Red Book: 2003. Report of the Committee on Infectious Diseases. 26. ed. Illinois, Elk Groove Village; American Academy of Pediatrics, 2003. p. 309-318.

2. ARGENTINA. MINISTÉRIO DE LA SALUD - Calendário nacional de vacunación de la República Argentina (2006). Available at http://www.msal.gov.ar/htm/site/ vacuna._cal2.asp.

3. ASSIS, S.B.; SOUTO, F.J.S; FONTES, C.J.E. \& GASPAR, A.M.C. - Prevalência da infecção pelos vírus das hepatites A e E em escolares do município da Amazônia Matogrossense. Rev. Soc. bras. Med. trop., 35: 155-158, 2002.

4. BIALEK, S.R.; THOROUGHMAN, D.A.; HU, D. et al. - Hepatitis A incidence and hepatitis A vaccination among American Indians and Alaska natives, 1990-2001. Amer. J. publ. HIth, 94: 996-1001, 2004.

5. BLACK, F.L. \& JACOBSON, D.L. - Hepatitis A antibody in an isolated Amerindian tribe fifty years after exposure. J. med. Virol., 19: 19-21, 1986.

6. BRASIL. MINISTÉRIO DA SAÚDE - Manual de normas de vacinação. 2001. Available at http://portal.saude.gov.br/portal/arquivos/pdf/manu_normas_vac.pdf.

7. CENTERS FOR DISEASE CONTROL - Prevention of hepatitis A through active or passive immunization: recommendations of the Advisory Committee on Immunization Practices (ACIP). Available at URL: ftp://ftp.cdc.gov/pub/Publications/ mmwr/rr/rr4812.pdf, 1999 and http://www.cdc.gov/mmwr/preview/mmwrhtml/ rr5507a1.htm?s_cid=rr5507a1_e, 2006.

8. CLEMENS, S.A.C.; FONSECA, J.C.; AZEVEDO, T. et al. - Hepatitis A and hepatitis B seroprevalence in four centers in Brazil. Rev. Soc. bras. Med. trop., 33: 1-10, 2000.

9. DAGAN, R.; LEVENTHAL, A.; ANIS, E. et al. - Incidence of hepatitis A in Israel following universal immunization of toddlers. J. Amer. med. Ass., 294: 202-210, 2005 .

10. DINELLI, M.I.S.; FISBERG, M. \& DE MORAIS-PINTO, M.I. - Anti-hepatitis A virus frequency in adolescents at an outpatient clinic in São Paulo, Brazil. Rev. Inst. Med. trop. S. Paulo, 48: 43-44, 2006.
11. FOCACCIA, R.; CONCEIÇÃO, O.J.G.; SETTE Jr., H. et al. - Estimated prevalence of viral hepatitis in the general population of the municipality of São Paulo, measured by a serologic survey of a stratified randomized and residence-based population. Braz. J. infect. Dis., 2: 269-284, 1998.

12. GAYOTTO, L.C.C.; QUARENTEI, A.A. \& CABRAL, G.L. - Soroepidemiologia das hepatites A e B nas regiões dos rios Biá e Alto Juruá, Amazônia Ocidental. GED, 3 106-112, 1984

13. GINSBER, G.M.; SLATER, P.E. \& SHOUVAL, D. - Cost-benefit analysis of a nationwide infant immunization programme against hepatitis A in an area of intermediate endemicity. J. Hepat., 34: 92-99, 2001.

14. LAFER, M.M.; DE MORAIS-PINTO, M.I. \& WECKX, L.Y. - Prevalence of IgG varicella zoster virus antibodies in the Kuikuro and Kaiabi indigenous communities in Xingu National Park, Brazil, before varicella vaccination. Rev. Inst. Med. trop. S. Paulo, 47: 139-142, 2005.

15. NUNES, H.M.; SOARES, M.C.P. \& SILVA, H.M.R. - Infecção pelo vírus da hepatite A em área indígena da Amazônia oriental brasileira. Rev. Soc. bras. Med. trop., 37(suppl. 2): S52-S56, 2004.

16. PAULA, V.S.; ARRUDA, M.E.; VITRAL, C.I. \& GASPAR, A.M.C. - Seroprevalence of viral hepatitis in riverine communities from the Western region of the Brazilian Amazon Basin. Mem. Inst. Oswaldo Cruz, 96: 1123-1128, 2001.

17. PEREIRA, F.E.L. \& GONÇALVES, S.C. - Hepatite A. Rev. Soc. bras. Med. trop., 36 387-400, 2003.

18. QUEIRÓZ, D.A.; CARDOSO, D.D.; MARTELLI, C.M. et al. - Risk factors and prevalence of antibodies against hepatitis A virus (HAV) in children from day-care centers, in Goiania, Brazil. Rev. Inst. Med. trop. S. Paulo, 37: 427-433, 1995.

19. SOKOL, R.J. \& NARKEVICZ, M.R. - Hepatitis A. In: HAY JR., W.W.; HAYWARD, A.R.; LEVIN, M.J. et al. Current pediatric diagnosis \& treatment. 16. ed. Denver, Lange, 2003. p. 659-662.

20. SANTOS, D.C.; SOUTO, F.J.; SANTOS, D.R.; VITRAL, C.L. \& GASPAR, A.M. Seroepidemiological markers of enterically transmitted viral hepatitis A and E in individuals living in a community located in the North Area of Rio de Janeiro, RJ, Brazil. Mem. Inst. Oswaldo Cruz, 97: 637-640, 2002.

21. TANNURI, U.; VELHOTE, M.C.; SANTOS, M.M. et al. - Pediatric liver transplantation: fourteen years of experience at the children institute in São Paulo, Brazil. Transplant. Proc., 36: 941-942, 2004.

22. WILLIAMS, R. - Prevalence of hepatitis A virus antibody among Navajo school children. Amer. J. publ. HIth, 76: 282-283, 1986.

23. ZAGO-GOMES, M.P.; STANTOLIN, G.C.; PERAZZIO, S. et al. - Prevalence of antihepatitis A antibodies in children of different socioeconomic conditions in Vila Velha, ES. Rev. Soc. bras. Med. trop., 38: 285-289, 2005.

Received: 19 July 2006

Accepted: 16 October 2006 